\section{Dutch monitor on stress and physical load: risk factors, consequences, and preventive action}

Irene L D Houtman, Anneke Goudswaard, Steven Dhondt, Maarten P van der Grinten, Vincent H Hildebrandt, Egbert G T van der Poel

\begin{abstract}
Objectives-Due to recent changes in legislation on occupational health and safety, a national monitor on stress and physical load was developed in The Netherlands to monitor (a) risks and consequences of stress and physical load at work, (b) preventive actions in companies to reduce these risks, and (c) organisational and environmental variables that facilitate preventive actions.
\end{abstract}

Methods-Information was gathered from employers, employees, and employees' representatives. The monitor was used with a nationally representative sample of companies in industry, wholesale trade, and banking and finance, 782 companies in total.

Results and conclusions-The information from the employees, aggregated at the company level, was not found to be correlated with that from the employer from the same companies. Although many employers do recognise risk factors for both physical load and stress as a problem they often seem to underestimate the problem when compared with employees or their representatives. This is particularly the case for psychosocial risk factors. Also, the perception of outcome measures, especially employers who consider emotional exhaustion to be work related, were fewer than the employees' representatives of the same organisation. Preventive measures on physical load are much more popular than measures against stress. It is the responsibility of the employer to take more preventive action of all kinds. They need to recognise risk factors as problems and health outcomes to be related to work. Employees of larger companies should participate with employers to consider effective measures, and more use should be made of support at branch level. For specific preventive measures, specific predictors emerged. Except for measures to prevent work stress, information from employees did not sufficiently contribute to the initiation of preventive measures in the workplace.

\section{(Occup Environ Med 1998;55:73-83)}

Keywords: work stress; physical load; health consequences; prevention at work

Dr Irene Houtman, NIA

TNO, PO Box 75665, 1070

AR Amsterdam,

The Netherlands.

Stress and musculoskeletal symptoms are reasons for disablement among two thirds of
Accepted 8 August 1997 the employees diagnosed to be disabled for work in The Netherlands. It is generally assumed that psychosocial risks at work are causal to work stress and psychological overload, whereas high physical exertion, awkward postures, repetitive movements, and heavy enduring static loads all lead to musculoskeletal symptoms. Recently, there are indications that psychosocial risks also contribute to the prevalence of musculoskeletal symptoms. ${ }^{12}$ Information from the Netherlands Bureau of Statistics ${ }^{3}$ indicates that especially the quantitative stress risks at work are continuously increasing. ${ }^{4}$ Dutch employees have the highest work pace scores in the European Union. ${ }^{56}$ In these studies, the Dutch rating on repetitive movements is found to be relatively unfavourable as well. Not only in The Netherlands, but in other countries as well, stress related symptoms and musculoskeletal symptoms are the main determinants of sick leave, and healthcare costs. ${ }^{7-10}$

In The Netherlands, the Dutch Working Environment Act (WEA) (1990) legislates on occupational health and safety issues. This includes an article which pays special attention to psychological wellbeing in the workplace, and more detailed guidelines on physical exertion at work. This legislation aimed to promote preventive action in the workplace. Due to the implementation of the European framework directive on health and safety, the WEA was updated in 1994. This resulted in a further stimulation of self regulation on occupational health and safety policy and practice within companies, and employers and employees are further committed to take responsibility for the employees' health, safety, and wellbeing.

These recent changes in legislation have enhanced the Government's need to monitor risks at work, health consequences, and preventive action at the company level. In 1992 the and Health develop a monitor for stress and physical work load. This had to be an instrument to monitor risks for, and consequences of stress and physical load (the main risks at work in The Netherlands), as well as preventive action taken by companies to control these risks. Indicators of several facilitating or inhibiting factors had to be included in the instrument as well. The information gathered with the monitor had to be obtained at the level of the employer, the employee, and the employees' representative. This information should then be used to $(a)$ provide steering information for the Ministry government made the TNO Division on Work 
important topics of their policy on occupational health and safety (stress and physical load), and (b) to feed back information to companies, under the assumption that employers would use this information to adjust the company policy on stress and physical load.

In 1993, the monitor was first used with almost 800 companies in industry, wholesale trade, and banking and financing. The present paper deals with the results of this first survey. In 1995 and 1996 the monitor study was repeated in these and the remaining branches of industry, and will thus cover the whole Dutch work force. The objective of this paper is to report on (a) the prevalence of risks and consequences of work stress and physical load as identified by employers, employees, and employee representatives; (b) the extent at which preventive actions are taken to control stress and physical load, and the kind of measures taken; $(c)$ the main preventive actions in the organisation, and the independent value of employee information when combined with employer information.

\section{Methods}

THE MONITOR

The monitor consists of two parts: (a) a structured interview for employer and employees' representatives, and $(b)$ a questionnaire for employees.

In constructing these two parts, national and international monitoring methods were selected and evaluated on evidence for reliability, validity, and usability. ${ }^{11}$ An abundance of questionnaires on risks and consequences on stress and physical load was found in the national and international literature. Many of these were tested on aspects of validity and reliability. A striking absence was noted of validated interviews for obtaining information from sources other than the employees themselves, especially on the topic of preventive policy and action.

To be included, the questionnaire and interview had to be concise and as efficient as possible, and parts of them should be related to national and international equivalents. Therefore, a multifaceted approach was used to construct them.

In the employee questionnaire parts of different questionnaires were combined. To measure work stress, the job content questionnaire $(\mathrm{JCQ})^{12}$ was used to obtain scales for the main dimensions for work stress risks - that is, quantitative job demands (work pace), skill discretion, and decision authority (autonomy). Also the questions on social support were included. To complement information on relations at work, a scale on relations with colleagues and supervisor from the Dutch questionnaire on work and health (VAG) was used. ${ }^{13}$ Finally, questions measuring decision authority with respect to working conditions, first tested in the Nova-Weba study were included. ${ }^{14}$

To measure consequences of stress, a questionnaire on emotional exhaustion (part of the Dutch MBI) ${ }^{15}$ and a 13 item questionnaire on psychosomatic complaints (VOEG) were included. ${ }^{16-18}$
Risks for physical load and musculoskeletal complaints were measured by a short version of the questionnaire on musculoskeletal load and health complaints, validated for Dutch employees (VBA). ${ }^{19}$ The VBA is partly based on the standardised nordic questionnaires for musculoskeletal symptoms. ${ }^{20}$

With respect to preventive actions, the employee had to indicate whether specific measures on stress or on physical load were taken, either directed at the work situation or at the worker. Also specific questions were asked on measures with respect to primary, secondary, or tertiary prevention, introduced in their department in the past 12 months.

For efficiency and coherence all questions were to be answered yes or no. Scales which were originally constructed with four (JCQ) or seven (MBI) answers were reformulated to be answered yes or no. As this might result in different psychometric properties of the questionnaire, aspects of validity and reliability will be looked into before conducting further analyses.

With respect to the preventive measures, the answer don't know was added to yes or no, to illucidate whether a preventive action did not take place, or whether the employee did not know if a particular measure was introduced.

Finally, several questions, considered relevant as mediating or moderating characteristics, were included - that is, questions on sex, age, education, job title, tenure, and shift work.

In the interview for employers and employee representatives, questions on risks and consequences to health from the employee questionnaire were always summarised. Firstly, employers and employee representatives were asked if they considered that a work pace was present in their organisation, and if they considered it to be a problem in their organisation. It was explained to the employer or employee representative that a high work pace was indicated by a lot of work, high work pace, and not enough time to finish things. So core parts of the employee questions used to construct a specific scale were used to illustrate the concept in the interview. For every risk dimension (decision authority, skill discretion, support and relations at work, force, awkward postures, vibrations, etc) one yes or no question was asked about the presence of the risk factor, and (if yes) a second if this risk factor was considered to be a problem. With respect to the health consequences, a question was asked if health complaints - for example, emotional exhaustion-had been raised by the employees in the past 12 months (yes or no). If these complaints had been raised, it was asked if they were considered to be work related (yes or no). In the case of emotional exhaustion it was explained to the employer or employees' representative that this was indicated by mental exhaustion, being fatigued in the morning, burned out, felt frustrated, felt at the end of one's rope, all were core parts of questions measuring emotional exhaustion in the employee questionnaire. Other health consequences - such as psychosomatic complaints, musculoskeletal complaints, and gen- 
eral health complaints-were checked in the interview in a comparable way.

Questions on preventive action were directed at the time of implementation (either in the past 12 months, before this 12 month period, or not at all), the type of measure (general measures, measures related to stress or physical load, measures related to workers or to work), and type of prevention (primary, secondary, or tertiary). Also, some questions were directed to the goal the employer wanted to obtain with the preventive measures, the evaluation of the measures, and the benefits obtained. These questions were partly based on interviews developed by Draaisma et $a l,{ }^{21}$ Laak and Olden, ${ }^{22}$ and Nossent and Klein Hesselink. ${ }^{23}$

With respect to structural prevention, questions were asked about available professional expertise in the organisation, including the presence or absence of an occupational physician, a special coordinator for health and safety issues, an ergonomist, an occupational hygienist, and a psychologist specialised in work (and health) issues.

General preventive measures were considered to attract expertise within the area of health and work - for example, by contracting an advice agency or research agency, by doing a risk assessment, or by doing research at the workplace. Research at the workplace may or may not have been specifically directed at work stress or physical load.

Measures to reduce work stress were specifically asked about, and could be courses or training (management training, courses directed at specifically managing work risks or specifically directed at the reduction of tension), task or job rotation, broadening of tasks, renewal of tasks, changing schedules, installation of regular formal work meetings.

Measures to reduce physical load were specifically asked about as well-such as courses, introduction of any apparatus to reduce heavy work, adjustment of task, job rotation, adjustment of the work place, or fitness programmes.

Finally, questions about potentially facilitating or inhibiting factors were included-such as size and socioeconomic position of the company, organisational characteristics (production structure, hierarchical levels). ${ }^{24}{ }^{25}$ Also, the attitude towards occupational health and safety in the branch of industry was assumed to influence the prevention policy of individual companies. Therefore questions on these topics were included as well.

Table 1 Content of the instrument

\begin{tabular}{|c|c|c|}
\hline Aspect & Questionnaire & Interview \\
\hline \multicolumn{3}{|l|}{ Risks: } \\
\hline \multicolumn{3}{|r|}{ Was aspect present in organisation? } \\
\hline Quantitative job demands & & Was aspect a problem in organisation? \\
\hline Skill discretion & & \\
\hline \multicolumn{3}{|l|}{ Decision authority (within tasks) } \\
\hline \multicolumn{3}{|l|}{ Social support/relations at work } \\
\hline \multicolumn{3}{|l|}{ Decision authority in working conditions } \\
\hline Physical load: & Scales on each aspect & Was aspect present in organisation? \\
\hline \multirow{2}{*}{\multicolumn{3}{|c|}{ Was aspect a problem in organisation? }} \\
\hline & & \\
\hline \multicolumn{3}{|l|}{ Awkward postures } \\
\hline \multicolumn{3}{|l|}{ Vibrations } \\
\hline Consequences: & Scales on each aspect & $\begin{array}{l}\text { Were complaints on specific aspect raised in the past } 12 \\
\text { months? }\end{array}$ \\
\hline \multicolumn{3}{|r|}{ Do you consider these complaints work related? } \\
\hline \multicolumn{3}{|l|}{ Emotional exertion } \\
\hline \multicolumn{3}{|l|}{ Psychosomatic complaints } \\
\hline Musculoskeletal problems: & Scales on each aspect & $\begin{array}{l}\text { Were complaints on specific aspect raised int he past } 12 \\
\text { months? }\end{array}$ \\
\hline \multicolumn{2}{|l|}{ Neck, upper back, and shoulder } & Do you consider these complaints work related? \\
\hline Lower back & (lower back $=1$ question) & \\
\hline \multicolumn{3}{|l|}{ Upper extremities } \\
\hline \multicolumn{2}{|l|}{ Lower extremities } & Not in interview \\
\hline General feeling of health & One question & \\
\hline Absenteeism & Not in questionnaire & Percentage last year; lower, equal, or higher than year before \\
\hline Turnover & Not in questionnaire & Percentage last year; lower, equal, or higher than year before \\
\hline Number of people diagnosed disabled for work & Not in questionnaire & Number diagnosed disabled; diagnosis \\
\hline Prevention: & Questions yes, no, or don't know & Questions past 12 months yes, no, before, or don't know \\
\hline \multirow{5}{*}{\multicolumn{3}{|c|}{$\begin{array}{l}\text { Structural aspects - for example, professional expertise } \\
\text { General measures } \\
\text { Stress and physical load } \\
\text { Individual, and work directed } \\
\text { Rehabilitation }\end{array}$}} \\
\hline & & \\
\hline & & \\
\hline & & \\
\hline & & \\
\hline \multirow[t]{16}{*}{ Potential mediators or moderators } & Personal characteristics: & Characteristics of the organisation: \\
\hline & & Size of company \\
\hline & & Type of social security insurance \\
\hline & Education & Commitment of employees in health and safety \\
\hline & Job title & Issues: \\
\hline & Permanent or temporary job & Social economic situation of company \\
\hline & Shift work & Centralised versus decentralised production \\
\hline & & Structure: \\
\hline & & Hierarchical levels in organisation \\
\hline & & Position of organisation in market \\
\hline & & Evaluation and general company policy with respect to \\
\hline & & $\begin{array}{l}\text { health and safety issues } \\
\text { Branch characteristics: }\end{array}$ \\
\hline & & Branch characteristics: \\
\hline & & $\begin{array}{l}\text { Activity of branch organisations with respect to health and } \\
\text { safety issues }\end{array}$ \\
\hline & & Specific support for reduction of work stress \\
\hline & & Specific support for reduction of physical load \\
\hline
\end{tabular}


Table 1 provides a summary of the topics on risks and consequences of stress and physical load, preventive policy and actions, and facilitating factors that were included in the employee questionnaire and in the structured interview for the employer and employees' representative.

\section{GENERAL PROCEDURE AND SAMPLING OF} COMPANIES

The field work was undertaken by the wage control service. This service, part of the Ministry of Social Affairs and Employment, contacted and visited the companies. The TNO performed most analyses. The wage control service took care of the feedback of information to the companies. This feedback was meant to stimulate and encourage wellbeing and health at work, especially in the companies in which the situation was worst.

Companies with 35 to 350 employees were selected and asked to participate. The sampling of companies was designed to produce a representative sample of the national distribution of company size (within the predetermined size range) and region in the selected branches of industry.

Within each company a random sample of employees was drawn: in companies with a maximum of 100 employees, 25 were randomly selected and asked to fill in a questionnaire. In companies of more than 100 employees, 35 employees were randomly selected and asked to fill in a questionnaire. If employers or companies refused to participate, another employer or company in the same branch of industry, about the same size, and in the same region was asked to participate. Companies were approached and visited from July to November 1993.

ANALYSES

The statistical analyses were performed in a stepwise order:

(1) Firstly, the quality of the monitoring methods was looked into. Factor analyses were performed to check the validity of the questionnaire structure. Homogeneity of the scales was tested with Cronbach $\alpha$. The additional value of individual items for scales was considered.
(2) To present prevalences, descriptive analyses were used. Information from the employee was always aggregated at the company levelthat is, for simple yes or no questions the percentage yes per organisation was determined, for scales average scores per organisation were calculated. Employee responses of an organisation were only included when at least 15 employees had returned valid questionnaires (out of 25-35 distributed questionnaires).

(3) The contribution of variables to explain preventive action at company level was tested with logistic regression analyses. Logistic regression was used because of the (sometimes extreme) skewness of the dependent variables. If variables were not a dichotomy themselves, as a rule they were dichotomised by way of a median split. To determine the independent contribution of the employee information, the regression analyses were performed in a stepwise order. In the first step only the independent variables as measured in the employer interview were entered. In the second step the (dichotomised) employee scales were entered as well. The significance of the increment in $\chi^{2}$ after entering the employee information was tested, taking into account the increase in degrees of freedom.

\section{Results}

RESPONSE

It was planned to include 880 companies in the study. Eventually 782 did participate. In only 376 companies (48\%) a works council (representation of employees) was found to be present, and in only 292 companies ( $78 \%$ of these 376) interviews with an employees' representative could take place. In 528 companies $(67.5 \%)$ questionnaires were distributed among a random sample of employees. A total of 7717 employees completed and returned the questionnaires. It was estimated that about 74000 employees worked in the 782 companies in the study sample. The employee sample thus constituted about $10 \%$ of the total number of employees. However, in only 287 companies more than 15 employees responded.

The distribution of companies in the sample across a branch of industry, company size, and

Table 2 Distribution of response percentages of organisations across branches: as planned, resulting from the employers' interviews, employees' questionaries, and interviews with employee representatives of the Works Council

\begin{tabular}{|c|c|c|c|c|}
\hline Branch & Plan $n(\%)$ & $\begin{array}{l}\text { Organisations with } \\
\text { employer interviews } \\
n(\%)\end{array}$ & $\begin{array}{l}\text { Organisations with } \\
\text { employee questionnaires } \\
n(\%)\end{array}$ & $\begin{array}{l}\text { Organisations with employee } \\
\text { representatives interviews } \\
n(\%)\end{array}$ \\
\hline Industry & $405(46)$ & $388(50)$ & $260(49)$ & $142(48)$ \\
\hline Foods and alied products & $(8.1)$ & $(9.5)$ & $(8.7)$ & $(9.5)$ \\
\hline Textile industry & $(-)$ & (3.5) & $(4.0)$ & (2.7) \\
\hline Clothing industry & $(-)$ & $(2.1)$ & (2.7) & $(0.7)$ \\
\hline Printing industry & $(6.8)$ & (6.6) & $(8.1)$ & $(7.4)$ \\
\hline Chemical industry & (5.6) & (4.9) & $(4.2)$ & (6.7) \\
\hline Metal industry & (9.8) & $(10.3)$ & (9.5) & (10.4) \\
\hline Machine industry & (9.4) & $(0.3)$ & $(0.4)$ & $(0.7)$ \\
\hline Electrotechnical industry & (6.2) & $(6.1)$ & (6.1) & (6.1) \\
\hline Means of transportation industry & $(-)$ & $(6.0)$ & $(5.5)$ & (3.7) \\
\hline Building industry & $(-)$ & $(0.1)$ & $(0.2)$ & $(0.3)$ \\
\hline Wholesale trade & $173(19.7)$ & $146(18.7)$ & $93(17.6)$ & $50(16.9)$ \\
\hline Banking and finance & $238(27.1)$ & $198(25.4)$ & $141(26.7)$ & $101(34.2)$ \\
\hline Banking and insurances & $(6.8)$ & $(6.2)$ & $(6.6)$ & $(7.8)$ \\
\hline Service sector (profit) & $(20.3)$ & $(19.2)$ & $(20.1)$ & $(26.4)$ \\
\hline Cleaning companies & $60(6.8)$ & $48(6.1)$ & $34(6.4)$ & $2(0.7)$ \\
\hline Total & $880(100)$ & $782(100)$ & $528(100)$ & $296(100)$ \\
\hline
\end{tabular}


Table 3 Percentage of employers who identify a specific risk factor as a problem, or health complaints to be work related

\begin{tabular}{|c|c|c|c|c|c|c|}
\hline & \multicolumn{2}{|l|}{ Industry } & \multicolumn{2}{|c|}{ Wholesale trade } & \multicolumn{2}{|c|}{ Banking and finance } \\
\hline & $\begin{array}{l}\text { Employer } \\
(n=388)\end{array}$ & $\begin{array}{l}\text { Employer - employee } \\
\text { representative }(n=142)\end{array}$ & $\begin{array}{l}\text { Employer } \\
(n=146)\end{array}$ & $\begin{array}{l}\text { Employer - employee } \\
\text { representative }(n=50)\end{array}$ & $\begin{array}{l}\text { Employer } \\
(n=198)\end{array}$ & $\begin{array}{l}\text { Employer - employee } \\
\text { representative }(n=101)\end{array}$ \\
\hline \multicolumn{7}{|l|}{ Stress risks as a problem: } \\
\hline Work pace & 16.5 & -14.9 & 13.7 & -8.0 & 23.2 & -3.0 \\
\hline Autonomy & 3.6 & -4.2 & 0.7 & -4.0 & 3.0 & -5.0 \\
\hline Skill discretion & 9.3 & -2.8 & 6.2 & -4.0 & 7.6 & 1.0 \\
\hline Autonomy in working cond. & 4.6 & -11.3 & 0.7 & -8.0 & 4.5 & 0 \\
\hline Relations & 13.1 & -5.0 & 6.2 & -4.0 & 8.6 & -8.9 \\
\hline \multicolumn{7}{|l|}{ Physical load as a problem: } \\
\hline Force & 22.2 & -7.7 & 19.2 & -4.0 & 8.1 & 1.0 \\
\hline Dynamic load & 12.9 & -6.3 & 7.5 & 0 & 4.0 & -2.0 \\
\hline Posture & 13.4 & 0.7 & 8.2 & 2.0 & 7.6 & -4.0 \\
\hline Vibrations & 3.1 & 0 & 2.7 & 0 & 0 & -2.0 \\
\hline \multicolumn{7}{|l|}{ Health outcomes as work related: } \\
\hline Emotional exertion & 27.5 & -4.1 & 30.8 & -9.4 & 38.9 & -8.3 \\
\hline Musculoskeletal problems & 44.8 & 11.7 & 41.1 & -7.6 & 31.3 & -8.3 \\
\hline
\end{tabular}

For those organisations from which both employer and employee representatives were interviewed, the difference between the percentages of employers and employee representatives identifying a specific risk factor as a problem or health complaint to be work related is presented. A negative difference indicates that less employers than employee representatives consider the risk to be a problem, or health outcome to be work related. Although the number of organisations in which both employers and employee representatives were interviewed was less than half of the original sample, the percentage of employers that considered a specific risk to be a problem generally was not very different. For industry, only the "social relations at work" and "force" were more often reported to be a risk by the employers in the small sample (difference $>5 \%$ ). In the wholesale trade, "work pace" was more often a problem in the small sample (difference $>5 \%$ ).

region was generally as planned (table 2). Only companies in the machine industry were represented less than originally planned, whereas companies in the transportation industry and companies of medium size (50-100 employees) were slightly overrepresented. The companies in which interviews with employee representatives had taken place were relatively large. This was to be expected as large companies (>35 full time equivalents) are legally obliged to have a works council.

The non-response in interviews with employees' representatives and in the employee questionnaires could have resulted in some sort of selection bias. When looking into the potential selection bias in interviews with employees' representatives, the only bias is that the interviews occurred more often in the larger companies of the present sample.

The distribution of employees across branches of industry who filled in questionnaires was almost the same as that of companies from which questionnaires were received. Despite this, the employee (questionnaire) response per organisation was relatively large in banking and finance, compared with industry and wholesale trade.

When comparing the distribution of professions across the different branches of industry, it shows the pattern that is expected, with the exception that supervisors are overrepresented in the data base compared with national reference data. ${ }^{3}$

FACTORIAL STRUCTURE AND HOMOGENEITY OF THE QUESTIONNAIRE DATA

Factor analysis of all employees' answers on questions indicating risks resulted in 12 scales with an Eigenvalue more than one. Because the dichotomous nature of the questions may introduce instability in the factor analyses, these analyses were also performed on subgroups (men $v$ women; older $v$ young employees). The results were almost identical in all subgroups. In the factor analysis on the whole sample, a total of $56.5 \%$ of the variance was explained. The original scales were found to be quite well represented by the factor structure.
Physical load constituted the first main factor (19.7\% of the variance explained). Almost all questions on physical risks depended on that factor. The question on sitting had a negative effect on this physical load factor, whereas bending forward, or twisting the neck, and often being in the same posture, showed no relation to it. Several of the physical load risks did, however, also consititute an individual factor (short cycle tasks, often taken postures or postures of long duration, and vibrations). Other factors that were identified were social relations at work (5.8\% variance explained; including the social support questions), skill discretion ( $4.7 \%$ variance explained), psychological demands (3.9\% variance explained), autonomy or decision authority at work $(2.5 \%$ variance explained), autonomy with respect to the workplace $(2.2 \%$ variance explained), flexible working hours $(2.1 \%$ variance explained), atmosphere at work (1.9\% variance explained), and shortage of personnel $(1.8 \%$ variance explained).

Homogeneity of the original scales, indicated by the Cronbach $\alpha$, was good $(0.61<\alpha<0.85)$, with the exception of the scale on autonomy with respect to working conditions $(\alpha=0.10)$. When the questions on social support were included in the scale measuring social relations, the indicator of homogeneity neither increased nor decreased. In further analyses the most economic short version of the social relations scale was used without the social support questions.

CORRESPONDENCE BETWEEN RATINGS OF EMPLOYER AND EMPLOYEE OR EMPLOYEES' REPRESENTATIVE

As the employer's responses are dichotomous variables, calculating correlations between employer's and aggregated employee scores on comparable risks and health outcomes is not completely appropriate. An alternative-such as the $\kappa$ indicator of correspondence-does not, however, properly takes into account the continuous nature of the employee information. Correlations are considered to give a simple and concise picture of the association 
Table 4 The preventative measures reported most often on work stress and physical load according to employers (companies could have implemented more than one type of measure)

\begin{tabular}{|c|c|c|c|c|c|}
\hline \multicolumn{3}{|c|}{ Work stress } & \multirow[b]{2}{*}{ Priority } & \multicolumn{2}{|l|}{ Physical load } \\
\hline Priority & Measures & $\begin{array}{l}\text { Employers } \\
(\%)\end{array}$ & & Measures & $\begin{array}{l}\text { Employers } \\
(\%)\end{array}$ \\
\hline 1 & Providing training courses & 6 & 1 & Individual changes in work or tasks & 44 \\
\hline 2 & Individual changes in work or tasks & 12 & 2 & Other tools, equipment, devices & 33 \\
\hline 3 & Other job in company & 11 & 3 & Adjusting work station & 28 \\
\hline 4 & Job rotation & 10 & 4 & Other job in company & 21 \\
\hline 5 & $\begin{array}{l}\text { Implementing regular work } \\
\text { consultation }\end{array}$ & 10 & 5 & $\begin{array}{l}\text { Providing training courses and } \\
\text { information }\end{array}$ & 19 \\
\hline 6 & Training course for supervisors & 10 & 6 & Individual advice & 13 \\
\hline 7 & Job enlargement & 8 & 7 & Job rotation & 13 \\
\hline 8 & Training course on the job & 8 & 8 & Other tasks & 11 \\
\hline 9 & Adjusting work schedule & 7 & 9 & Physical fitness course & 4 \\
\hline 10 & Individual counselling & 7 & 10 & Individual physical training & 2 \\
\hline
\end{tabular}

between the employer's perception, and the average perception of the employees in the organisation. Also Student $t$ tests were performed to test if the average employees' scores on risks in companies were higher when employers indicated these risks to be present, or to be a problem, compared with the situation when this was not the case. These tests were also used to test if employees' scores on health outcomes are higher in companies where employers say these complaints have been raised or were considered to be work related. The $t$ tests resulted in the same conclusion as the correlational analyses: the correspondence in ratings on risks and health consequences was poor between employer and employees. There was no correlation between the answers of the employer to the question of whether or not employees in their organisation were confronted with a specific risk, or if they considered that risk to be a problem, and the mean score of the scale measuring that risk factor from employees of the same company. All but two of the correlations were equal or lower than $r=0.25$. The only exceptions concerned the risks of force (exertion) and dynamic load $(0.30<r<0.41)$. Also no systematic correlations were found between the answers of employers and the mean score of employees from the same organisation indicating that health problems had been raised in the past year, or were considered to be work related.

The correlations between the answers of the employer and employees' representative were low to moderately high for the risks present (ranging from $0.40-0.65$, depending on the risk), but were absent to moderate for the identification of risks as problems (ranging from 0.07 for autonomy to 0.53 for force). Employers and employees' representatives thus only partly agree on the identification of risks for work stress and physical load, and disagree on

Table 5 Odds ratios (OR) (95\% CI) resulting from logistic regressions on professional expertise employed by the company in the field of health and safety, measures taken last year in general, or specifically related to work stress, to physical load and rehabilitation: only the significant predictors are shown (results from analyses on organisations with a response of $\geqslant 15 ; n=287$ )

\begin{tabular}{|c|c|c|c|c|c|}
\hline & \multicolumn{5}{|c|}{ Preventive policy or measures } \\
\hline & \multirow{2}{*}{$\begin{array}{l}\text { Professional expertise } \\
O R(95 \% C I) \\
\left(\chi^{2}=55.4, d f=28,\right. \\
\left.R_{M L}^{2}=0.18\right)\end{array}$} & \multirow{2}{*}{$\begin{array}{l}\text { General measures } \\
O R(95 \% C I) \\
\left(\chi^{2}=150.5, d f=28,\right. \\
\left.R_{M L}^{2}=0.41\right)\end{array}$} & Work stress & Physical load & Rehabilitation \\
\hline & & & $\begin{array}{l}\text { OR }(95 \% C I) \\
\left(\chi^{2}=124.2, d f=28,\right. \\
\left.R_{M L}^{2}=0.41\right)\end{array}$ & $\begin{array}{l}\text { OR }(95 \% C I) \\
\left(\chi^{2}=95.3, d f=28,\right. \\
\left.R_{M L}^{2}=0.28\right)\end{array}$ & $\begin{array}{l}O R(95 \% C I) \\
\left(\chi^{2}=37.3, d f=28,\right. \\
\left.R_{M L}^{2}=012\right)\end{array}$ \\
\hline \multicolumn{6}{|l|}{ Employee: } \\
\hline Work pace & $0.4 \quad(0.21$ to 0.84$)$ & - & $2.1(1.05$ to 4.12$)$ & $0.5(0.22$ to 1.13$)$ & - \\
\hline Autonomy & - & $0.4(0.20$ to 0.97$)$ & - & - & - \\
\hline Skill discretion & - & - & $0.4 \quad(0.22$ to 0.85$)$ & - & - \\
\hline Physical load & - & - & $2.6(1.22$ to 5.49$)$ & - & - \\
\hline \multicolumn{6}{|l|}{ Employer: } \\
\hline $\begin{array}{l}\text { Employer identifies work stress risks as a } \\
\text { problem }\end{array}$ & - & - & $1.9^{\star}(0.92$ to 3.97$)$ & - & $1.7^{\star}(0.91$ to 3.27$)$ \\
\hline $\begin{array}{l}\text { Employer identifies risks for physical load } \\
\text { as a problem }\end{array}$ & - & $2.06^{\star}(0.90$ to 4.74$)$ & - & - & - \\
\hline $\begin{array}{l}\text { Employer identifies exhaustion to be work } \\
\text { related }\end{array}$ & $2.7 \quad(1.19$ to 5.94$)$ & - & 3.0 (1.39 to 6.42$)$ & $\begin{array}{l}4.2(1.74 \text { to } \\
10.06)\end{array}$ & - \\
\hline $\begin{array}{l}\text { Employer identifies musculoskeletal } \\
\text { problems to be work related }\end{array}$ & $1.8^{\star}$ & 0.90 to 3.54 & 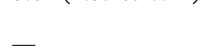 & - & - \\
\hline Absenteeism & 1.0 & - & - & $\overline{2.6}(1.20$ to 5.79$)$ & - \\
\hline $\begin{array}{l}\text { Involvement of employees in } \\
\text { implementing preventive policy } \\
\text { Good socioeconomic position of the }\end{array}$ & $1.9^{\star}(0.98$ to 3.64$)$ & $2.55(1.18$ to 5.53$)$ & - & - & - \\
\hline company & - & - & $3.4(1.19$ to 9.94$)$ & - & - \\
\hline Company size $>100$ employees & $2.0 \quad(1.00$ to 4.08$)$ & 6.5 (2.97 to 14.12$)$ & $2.0 \quad(1.02$ to 4.02$)$ & $2.2^{\star}(0.90$ to 5.16$)$ & - \\
\hline Use of support at branch level & $2.3(1.17$ to 4.46$)$ & - & $2.5(1.25$ to 5.08$)$ & $2.7(1.27$ to 5.90$)$ & - \\
\hline Branch activities directed at stress & - & - & 9.0 (3.02 to 26.82 ) & - & - \\
\hline Branch activities directed at physical load & - & - & $0.5(0.23$ to 1.04$)$ & - & - \\
\hline A lot of teamwork & - & 3.8 (1.5 to 9.68$)$ & - & 3.11 (1.09 to 8.89$)$ & - \\
\hline Follower of the market & - & - & - & - & - \\
\hline A weak input of materials & $2.6^{\star}(0.97$ to 6.91$)$ & - & - & - & - \\
\hline A weak labour market & - & - & - & - & $0.5 \quad(0.29$ to 0.99$)$ \\
\hline Measures were found effective & - & 3.8 (1.87 to 7.58$)$ & 5.6 (2.91 to 10.95$)$ & $3.8(1.63$ to 8.69$)$ & $2.8 \quad(1.56$ to 4.94$)$ \\
\hline
\end{tabular}

$\star 0.05<\mathrm{p}<0.10$. 
whether these risks constitute a problem to the organisation.

Many of the employers, however, do recognise the presence of work risks. Only a subgroup of them also identified these risks as a problem in their organisation.

Table 3 shows the difference between employers and employees' representatives, who both were asked the same question. The figures consistently show that, in particular for the risks of work stress, a higher proportion of employees' representatives considered risks to be a problem in the company. The difference between employers and employees' representatives was highest for work pace.

For employers in industry and wholesale trade the main problems were force and work pace, whereas in banking and finance work pace was by far the main problem. From table 3 it can be seen that autonomy and vibrations were rarely considered to be problems.

Not only were the stress risks less often considered to be a problem by employers compared with employees' representatives, but also health complaints were less often considered to be work related by employers. The only exception was musculoskeletal complaints in industry, which were considered to be work related more often by the employer than by the employees' representative.

PREVENTIVE ACTION, ESPECIALLY DIRECTED AT WORK STRESS AND PHYSICAL LOAD

Responses of employers and employees' representatives on the questions about preventive measures taken in the past 12 months coincided to a large extent. The figures show that there has been an important increase in the amount of preventive actions since 1993. It seems probable that this recent increase is due to the updated legislation already described.

About $21 \%$ of the companies publish a working conditions policy plan, whereas about $20 \%$ of the companies are developing such a plan. In about $30 \%$ of these plans physical load is an important topic, whereas in only $16 \%$ is work stress important. A general risk assessment on working conditions has been performed by $25 \%$ of the employers. One out of five companies has published a report on its working conditions policy for the previous year, including an overview of sickness absenteeism, turnover, and work disablement. About half of the companies state that they relate their working conditions policy to other management topics, in order of importance: policy towards sickness absenteeism; social policy; environmental policy; and total quality management.

In the previous year about $12 \%$ of the employers have carried out a study into physical load, and only $3 \%$ into stress. Table 4 shows the most reported preventive measures to limit work stress and physical load. As there were generally only minor differences between the ratings given by the employers and by the employees' representatives, only the employer's information is presented here.

Table 4 shows that preventive measures against physical work load were much more popular than measures against stress. Preventive measures directed at either stress or physical load were related to changing the work situation and the individual employee (improving work capacity). However, when comparing preventive measures against stress with those against physical load, the most prominent preventive measures against physical load were more often directed at changing the work situation.

OBJECTIVES FOR IMPLEMENTING PREVENTIVE MEASURES TO LIMIT WORK STRESS AND PHYSICAL LOAD

Those companies that reported taking preventive actions against work stress or physical load were asked their reasons for doing so (maximum of three per company). According to both the employers and the employees' representatives there were three main reasons: decreasing sickness absenteeism (29\%, both employers and employees' representatives), increasing productivity (employers 13\%, employees' representatives $8 \%$ ), and increasing employee motivation (employer $11 \%$, employees' representatives $8 \%$ ).

About $50 \%$ of all employers said that they have evaluated their preventive actions (25\% according to the employees' representatives). In general, the employers reported various positive effects: $68 \%$ of those employers who evaluated their preventive actions reported positive effects on employee motivation $(36 \%$ by the employees' representatives), $60 \%$ reported a decrease in sickness absence $(26 \%$ by the employees' representative), almost 50\% reported a better social climate $(21 \%$ by the employees' representative), and $40 \%$ reported an improved productivity ( $24 \%$ by the employees' representative). The data clearly show that preventive actions were evaluated more positively by employers than by employee representatives.

FACTORS FACILITATING PREVENTIVE ACTION

Table 5 shows the results of the logistic regressions for various dependent measures: the amount of professional expertise present in the organisation; the number of general preventive measures taken; number of measures taken directed at the prevention of work stress; the number of measures taken directed at the prevention of physical load; as well as measures directed at rehabilitation (tertiary prevention). In all analyses, the dependent measure was split at the median, which meant that the reference in all analyses was zero measures.

Table 5 shows that the predictor sets generally explained the dependent measures well, in particular the general and specific measures, and to a lesser extent the professional expertise, and the rehabilitation policy. The strength of the logistic model is represented by $\mathrm{R}^{2}$ ML which was calculated with the Maddala formula based on a transformation of the likelihoodratio

$$
\mathrm{R}^{2}{ }_{\mathrm{ML}}=1-\mathrm{e}-\left(\chi^{2} / \mathrm{N}\right) .^{26}
$$

The $\mathrm{R}_{\text {ML }}^{2}$ is considered comparable with the $\mathrm{R}^{2}$ in linear regression. 
Information of the employees only contributed significantly to the explanation of company differences in the number of stress measures taken. The employee information tended to contribute to the number of general measures taken, but not at all to the number of measures directed at physical load and rehabilitation.

Independent factors associated with companies that have increased their professional expertise in the past 12 months compared with those that have not were: employer information, employer identified emotional exhaustion and musculoskeletal problems as work related; were larger in size; used support in prevention at branch level; tended to involve employees in implementing the preventive policy; and to have a weak input of materials (probably relevant in wholesale trade and industry). Surprisingly, the companies that have taken on professional expertise scored poorly on work pace, according to the employees.

Independent factors differentiating companies that have taken general measures in the past 12 months compared with those that have not taken any (employer information) were involving employees in implementing preventive policy; were larger; had a lot of team work; and measures were found to be effective. There was a tendency for risks for physical load to be considered a problem. According to the employees, the autonomy was high (low employee score) in these companies.

Independent factors differentiating companies that have taken measures to prevent work stress in the past 12 months compared with those that have not taken any (employer information) were: employer identified emotional exhaustion to be work related; a better socioeconomic position; larger companies; use of support at branch level, branch activities were specifically directed at stress; and measures were found to be effective. There was also a tendency for employers to identify work stress risks as a problem, and for that branch of industry to be low on measures against physical load. Information from the employees contributed considerably in differentiating between companies that had taken measures against work stress in the past 12 months and those that had not. More measures had been taken in companies where employees indicated a high work pace, high skill discretion, and high physical load.

Independent factors differentiating companies that have taken measures to prevent physical load in the past 12 months and those that have not taken any (employer information) were: employer identified emotional exhaustion and absenteeism to be work related; use of support at branch level; a lot of team work; and measures to be found effective. There was a tendency for larger companies to take more of these kinds of measures.

Hardly any differentiating factors between companies that do or do not do anything about rehabilitation were found. The few independent factors differentiating companies that have taken rehabilitative measures in the past 12 months and those that have not taken any (employer information) were a weak labour market and measures were found to be effective. There was a tendency for employers to identify risks for work stress to be a problem.

Thus independent factors that at least two out of five times consistently differentiated between companies that have taken measures, either general or more specific ones, were: the employer to recognise either a risk factor as a problem or health outcomes to be work related; a larger organisation; support at branch level; whether the employer considered the measures or policy to be effective; and more employee involvement (only for the general measures). The employer's identification of a symptom being work related more often contributed to preventive action than the employer's identification of risks at work as problems.

The regression analyses have only been performed on the 287 companies for which both employer and employee information (>14 employee) was available, as a large enough employee response was obtained from less than half of the companies that originally participated in the study. The analyses of the first step in the logistic regression with employer information only was repeated for the whole sample of 778 companies. In general, almost all variables, which contribute to the five dependent measures of preventive action in the first step in the logistic regression on the small sample $(n=287)$, emerged as significant predictors in the first step on the total sample $(\mathrm{n}=778)$ as well, with comparable odds ratios. Only small differences were found between the results of the two analyses, largely explained by the lower threshold for significant odds ratios in the large sample.

\section{Discussion and conclusions}

In this study information is provided on the prevalence of risks and consequences, as identified by employees, employees' representatives, and employers, as well as information on the prevalence and determinants of preventive actions at the company level, in three major branches of industry. The results lead to the conclusion that employers do recognise that risk factors at work can be a problem. In comparison with employees or employees' representatives, however, they often seem to underestimate the problem. This is particularly the case for work stress risks. It might be argued that it is the employee or employees' representative who is overestimating, although it is difficult to tell the norm in situations in which, by way of self report, information is gathered from different people with different interests. Self reporting, however, gives valuable information and publications consistently indicate that the self reported presence of stress risks and health problems themselves do have significant and independent prognostic value in predicting mortality and morbidity. ${ }^{27-30}$ Self reporting, also from employees, must therefore always be considered as a potentially important signal.

From the risks mentioned for work stress, work pace was most often considered to be a 
problem. Relations at work were regularly considered problematic as well. Autonomy, on the other hand, was hardly considered to be a problem, both by employers and by employees' representatives. These results accord, to some extent, with the results from the study by the European Foundation, which identified the Dutch employees relative to employees in other European Union countries as having the most unfavourable work pace, but the most favourable autonomy. ${ }^{56}$ Within the framework of the job demand job control model-one of the most popular work stress models at present-it is stated that the combination of high job demands and low control are especially related to several ill health outcomes. From these theoretical notions, job strain is expected not to be very high in the Dutch work force. The scores on psychological health complaints as measured in the European Union survey confirm this finding. These figures, however, conflict with the notion that so many employees drop out of work due to psychological problems (and one third of all drop out due to health problems). As the European Union surveys were cross sectional in nature, the hypothesis of a healthy worker selection may explain this contradiction.

Longitudinal studies of the processes of dropout in greater detail are, however, still scarce and therefore highly warranted.

Another explanation for the high work pace in combination with high autonomy, low psychological health complaints, but a high dropout from work due to psychological problems may be the changes in the work situation: the increase in flexibility (flexible working hours, flexible work places) and working with information. These changes make it possible more often to do work at home, and in the evenings and weekends. ${ }^{31}$ This means that although the employee may be very autonomous and is able to develop skills, work and private life become more and more entangled. It is reported that chronic entanglement of work and private life is associated with more chronic fatigue. $^{31}$

The finding that employers seem to underestimate risks in general, and stress risks in particular, may be interpreted by employers still failing to identify stress as a problem. This may also explain why relatively few measures directed at the reduction of work stress were reported.

The finding that employee information significantly contributed only to the measures to limit stress may indicate that especially in the case of work stress, measures are taken just to meet the complaints about stress risks by the employees. Stress directed measures were, however, likely to be taken also when the financial status of the organisation was considered to be good.

The results showed a strong increase in preventive measures taken the year preceding the interview than before. This increase is probably related to the implementation of the updated and renewed legislation on occupational health and safety in The Netherlands, which occurred a few months after the launch of this study. The reported preventive measures were directed both at the work and at the workers. Preventive measures against physical load were found to be much more popular than those for work stress. Consistent with other publications, training was the most common measure against work stress, and specific work directed measures were taken less often. Kahn and Byosiere $^{32}$ have commented on this "flood of practitioner activity in the field of stress reduction and stress management". Today, stress management seems to be a booming market and an industry of its own. ${ }^{33}$ This market has been characterised by Martin ${ }^{34}$ as a market in which the most widespread demand is rapid, low cost training that at least quiets employees' complaints, if not their stress.

In contrast to measures on work stress, measures on physical load are primarily directed towards the workplace and work tasks, and are most often of an ergonomic nature. Measures directed at physical load are often taken at the worker level, although adjustments to the workstation and to tools, and modification or use of equipment and devices are also common. Measures directed towards individual capabilities of the worker are less common in the domain of physical load.

A variable that was often found to be associated with general measures in particular is a high degree of employee participation. Variables related to general as well as specific measures are: a larger size of the organisation; more use of support in prevention at branch level; and the fact that the measures were considered to be effective by the employer. Reviews on intervention studies implementing different kinds of preventive measure ${ }^{35}{ }^{36}$ show that employee participation can be an important success factor for specific measures as well.

More use of support at branch level is systematically found to be related to more preventive action. This may, however, be related to the offer at branch level, as well as to a more active role of the company itself. The fact that specific branch activities were found to independently contribute to specific preventive measures leads to the conclusion that both the specific branch activities directed either at work stress or physical load and a more active role of the company itself, facilitate specific preventive actions at the company level.

The logistic regressions that differentiate (and may be able to offer prognosis) between companies that took preventive measures and those that did not, do not completely coincide with the reasons the employers provide for investing in preventive action. The main objective, and main effect as reported by the employers for taking preventive measures, is a reduction in absenteeism, next to increasing productivity (not fully discussed in this study) and increasing motivation. Absenteeism was only found to significantly enter the logistic regression on measures directed at physical load. Relations at work, which affect motivation, either as the employee (average) score, or as the employer's recognition of this risk factor as a problem, was not found to significantly contribute to the explanation of any 
preventive measure. It is striking that preventive measures on physical load are not associated with the employers' identification of physical load as problematic or with their perception that musculoskeletal problems are work related, but, apart from absenteeism, are associated strongly with employers' identification of work related emotional exhaustion. This could mean that employers are focusing measures mainly on high energetic (mental or physical) loads and are less familiar with the work related health effects of more static working situations and measures to prevent these types of problems. The relatively low percentage of employers (and employees' representatives) in banking and finance reporting posture as a problem and reporting musculoskeletal problems as work related (table 3) could be indicative of this phenomenon.

The explanation of measures directed at rehabilitation is an exception on the more general statement already made. Rehabilitative measures were only marginally explained. Some explanatory power comes from a weak labour market, and when measures were considered to be effective.

The logistic regressions showed considerable stability among the predictor sets: both for the various dependent measures, and across sample size. For sample size, it was companies from the branches of industry and wholesale trade in particular that were lost when only companies with a response of 15 employees or more were used. This reduction resulted, however, only in minor changes in the predictor set that best explained the dependent variable, both for the specific variables that emerged, and the magnitude of the odds ratios. This stability in predictor sets despite a relative selective reduction in sample size suggests that the predictor sets of the preventive measures are relatively similar across different employment sectors.

This study of monitoring is quite unique in its aims, its specific focus on work stress and physical load, and on the explanation of preventive measures with information from both employers and employees. Of course we have to be careful to infer causal relations from the cross sectional data in the present study. Also, preventive action was taken as the dependent variable, and was assumed to be explained by the perception on risks, health outcomes, and some general organisational and branch aspects, instead of the other way around: risks and consequences as to be determined by preventive action. Both directions of causality are plausible, and should both be tested in the future, when a longitudinal data set is present. Especially when testing the independent effects of employee information, measures should be taken to increase the sample size of employees.

This research was supported by the Dutch Ministry of Social Affairs and Employment. This paper could not have been writcontrol service of this Ministry.

1 Bongers PM, Winter CR de, Kompier MAJ, et al. Psychosocial factors and musculoskeletal disease: a review of the litcial factors and musculoskeletal disease: a review of the

2 Houtman ILD, Bongers PM, Smulders PGW, et al. Psychosocial stressors at work and musculoskeletal problems. Scand $\mathcal{F}$ Work Environ Health 1994;20:139-45.
3 Central Bureau of Statistics. Life situation survey 1977-1989/ continuous life situation survey 1990-1995: core figures continuous life situation survey 1990-1995: core figures Keefsituatie Onderzoek/Doorlopend Leefsituatie Onders). Heerlen: CBS, 1979-1990/1991-1996.

4 Houtman ILD, Kompier MAJ. Risk factors and occupational risk groups for work stress in the Netherlands. In: SL Sauter, LR Murphy, eds. Organisational risk factors for job stress. Washington: American Psychology Association, 1995:209-25.

5 Paoli P. First European survey on the work environment 1991-2. Dublin, Ireland: European Foundation for the Improvement of Living and Working Conditions, 1992.

6 Paoli P. Second European survey on the work environment 1995-6. Dublin, Ireland: European Foundation for the Improvement of Living and Working Conditions, 1997.

7 O'Leary L. Mental health at work. Occupational Health Review 1993;23-6.

8 Davies NV, Lunde Jensen P, Marshall N, et al. The economic appraisal of European Union Health and Safety at Work Legisappraisal of European Union Health and Safety at Work LegisReport to the EC.)

9 Manning MR, Jackson CN, Fusilier MR. Occupational stress and health care use. Fournal of Occupational Health Psychology 1996;1:100-9.

10 Koningsveld EAP, Mossink JCM, eds. Core figures societal costs of working conditions and occupational health and safety Kernciffers maatschappelijke kosten van arbeidsomstandigheden). The Hague: Vuga: 1997.

11 Houtman ILD, Hildebrandt VH, Dhondt S. Monitoring stress and physical load: develop ment and first test of an instrument (Monitoring stress en lichamelijke belasting: constructie en eerste test van een instrumentarium). Leiden: NIPG-TNO, 1993. (Publ No 93.075.)

12 Karasek RA. Job demands, job decision latitude, and mental strain: implications for job redesign. Administrative Science Quarterly 1979;24:285-308.

13 Grundemann RWM, Smulders PGW, Winter CR de. Manual of the questionnaire on work and health (Handleiding Vragenlijst Arbeid en Gezondheid). Lisse: Swets en Zeitlinger 1993.

14 Houtman ILD, Bloemhoff A, Dhondt S, et al. WEBA and nova-WEBA in relation to health and well-being of employees (WEBA en Nova-WEBA in relatie tot gezondheid en welbevinden van werknemers). Leiden: PG-TNO, 1994. (Publ No 94.003.)

15 Schaufeli WB, Maslach C, Marek T. Professional burnout: recent developments in theory and research. New York: Taylor and Francis, 1993.

16 Dirken JM. Work and stress (Werk en stress). Groningen: Wolters Noordhoff, 1969.

17 Joosten J. Drop MJ. The reliability and comparability of three versions of the VOEG (De betrouwbaarheid en three versions of the VOEG (De betrouwbaarheid en heid en Samenleving 1987;8:251-65.

18 Sonsbeek JLA van. The VOEG: a complaint questionnaire or a questionnaire on health problems? (De Voeg: een klaaglijst of lijst voor gezondheidsklachten). Statistische Onderzoekingen. Den Haag: SDU/Uitgeverij. 1990. (M 37.)

19 Hildebrandt VH, Douwes M. Physical load and work: questionnaire on musculoskeletal load and health complaints (Lichamelijke belasting en arbeid: vragenlijst bewegingsappa raat). Voorburg: Ministry of Social Affairs and Employment, 1991. (S122-3.)

20 Kuorinka 1, Jonsson B, Kilbom A. Standardised nordic questionnaires for the analysis of musculoskeletal symptoms. Applied Ergonomics 1987;18:233-7.

21 Draaisma D, Winter CR de, Dam J, et al. Quality and effectiveness of occupational health care: judgements of client organizations, comparisons with the judgements of experts (Kwaliteit zations, comparisons with the judgements of experts (Kwaliteit en effectiviteit van de bedrijfsgezondheidszorg: oordelen van client organisaties, vergelijkingen

22 Laak PJA van de, Olden JT. Economic and juridicial factors and their relation to the safety policy in organizations Economische en juridische factoren en hun relatie met het veiigheidsbeleid van ondernemingen). Den Haag: Ministerie van Sociale Zaken en Werkgelegenheid. 1992:S-149.

23 Nossent SM, Klein Hesselink DJ. Branch organizations at work for healthy work (Bedrijfstakorganisaties aan de arboslag). Den Haag: Ministerie van Sociale Zaken en Werkgelegenheid, 1992:S-135.

24 Kuipers H, Amelsvoort P. van. Effective organizing: introduction to the sociotechnical approach as an integral design theory (Slagvaardig organiseren: inleiding in de sociotech niek als integrale ontwerpleer). Deventer: Kluwer bedriffswetenschapgrale ontwerpl 1990.

pen, 1990 .
25 Vaas $S$, Dhondt S, Peeters MHH, et al. The WEBA-method. part 1: WEBA analysis manual (in Dutch: De WEBAmethode. Deel 1: WEBA-analyses handleiding). Alphen aan de Rijn: Samson, 1995.

26 Scott Long J. Regression models for categorial and limited dependent variables. Thousand Oaks, CA: Sage, 1997.

27 Bosma H. Appels A, Sturmans F, et al. KRIS follow-up IX. Tijdschrift voor Sociale Gezondleidszorg 1991;69:299-305.

28 Rosengren A, Tibblin G, Wilhelmsen L. Self-perceived psychological stress and incidence of coronary artery disease in middle-aged men. Am $\mathcal{F}$ Cardiol 1991;68:1171-5.

29 Schnall PL, Landsbergis PA, Baker D. Job strain and cardiovascular disease. Annu Rev Public Health 1994;15: 381-411.

30 Siegrist J, Peter R, Junge A, et al. Low status control, high effort at work and ischaemic heart disease: prospective evi-
dence from blue-collar men. Soc Sci Med 1990;31:112734 . 
31 Zijlstra FRH, Schalk MJD, Roe RA. Changes in work: consequences for the employees (In Dutch: Veranderingen in arbeid: consequenties voor de werkenden). Tijdschrift voo Arbeidsvraagstukken 1996;12:251-63.

$32 \mathrm{Kahn} \mathrm{Rl,} \mathrm{Byosiere} \mathrm{P.} \mathrm{Stress} \mathrm{in} \mathrm{organizations.} \mathrm{In:} \mathrm{RA}$ Dunnette, MB Hough, eds. Handbook of industrial and organizational psychology (2nd ed). Palo Alto, CA: Consulting Psychology Press, 1990:571-650.

33 Houtman ILD, Kompier MAJ. Courses on work stress: a growing market, but what about their quality? In: LR Murphy, JL Hurrell, SL Sauter, et al, eds. fob stress interventions. Washington, DC: American Psychology Association, $1995,337-50$
34 Martin EV. Designing stress training. In: JC Quick, LR Murphy, JJ Hurrell Jr, eds. Stress and well-being at work: assessments and interventions for occupational mental health. Washington DC: American Psychology Association, 1992:207-24.

35 Kompier MAJ, Grundemann RWM, Vink P, et al. Start working: 10 examples from practice to successfully manage absenteeism (In Dutch: Aan de slag! Tien praktijk voorbeelden van succesvol verzuimmanagement). Alphen aan de Rijn: Samson, 1996.

36 Karasek R. Stress prevention through work reorganization: a summary of 19 international case studies. In: Jankanish MB, ed. Conditions of work digest. Preventing stress at work. Geneva: International Labour Organisation, 1992;11:23-275.

\section{Vancouver style}

All manuscripts submitted to Occup Environ Med should conform to the uniform requirements for manuscripts submitted to biomedical journals (known as the Vancouver style.)

Occup Environ Med, together with many other international biomedical journals, has agreed to accept articles prepared in accordance with the Vancouver style. The style (described in full in the $f A M A[1])$ is intended to standardise requirements for authors, and is the same as in this issue.

References should be numbered consecutively in the order in which they are first mentioned in the text by Arabic numerals on the line in square brackets on each occasion the reference is cited (Manson[1] confirmed other reports[2] [3] [4][5]). In future references to papers submitted to Occup Environ Med should include: the names of all authors if there are three or less or, if there are more, the first three followed by et al; the title of journal articles or book chapters; the titles of journals abbreviated according to the style of Index Medicus; and the first and final page numbers of the article or chapter. Titles not in Index Medicus should be given in full.

Examples of common forms of references are:

1 International Committee of Medical Journal Editors. Uniform requirements for manuscripts submitted to biomed journals. fAMA 1993;269:2282-6.

2 Soter NA, Wasserman SI, Austen KF. Cold urticaria: release into the circulation of histmaine and eosinophil chemotactic factor of anaphylaxis during cold challenge. $N$ Engl F Med 1976;294:687-90.

3 Weinstein L, Swartz MN. Pathogenic properties of invading micro-organisms. In: Sodeman WA Jr, Sodeman WAading micro-organisms. In: Sodeman WA Jre Sodeman
WA, eds. Pathologic physiology, mechanisms of disease. PhilaWA, eds. Pathologic physiology, mechanis
delphia: W B Saunders, 1974:457-72. 